\title{
FARMER PERCEPTION ON THE EFFECTIVENESS OF INTEGRATED WEED MANAGEMENT METHODS IN PUNJAB, PAKISTAN
}

\author{
Abdul Wahhab Arshed*, Khalid Mahmood Ch., Ijaz Ashraf, M Iqbal \\ Department of Agricultural Extension, University of Agriculture, Chak No. 247 G.B. Tehsil \& \\ District Toba Tek Singh, Faisalabad, Pakistan
}

Accepted: 06 October 2011

\begin{abstract}
Weeds reduce crop yield up to a great extent. Farmers use Integrated Weed Management (IWM) to eradicate weeds. The present study was conducted to assess farmer's perception regarding the effectiveness of various weed control methods utilized under the umbrella of IWM in the Punjab province of Pakistan. Information were collected from 150 randomly selected farmers from three divisions of Punjab viz Faisalabad, Rawalpindi and Dera Ghazi Khan. The study revealed chemical methods as the most effective weed control tool followed by cultural methods and mechanical methods. Preventive measures were ranked as $4^{\text {th }}$ and biological methods as the last.
\end{abstract}

Key words: Integrated Weed Management, Weed Control Methods, Farmer Perception

\section{INTRODUCTION}

Agriculture is the back bone of Pakistan's economy, contributing $21 \%$ share in GDP and employing $43 \%$ of the total labor force (Govt of Pakistan 2011). So, the development in the field of agriculture means the wellbeing of 180 million people in Pakistan.

Wheat, Cotton, Sugarcane and Rice are the major field crops sown in Pakistan. But yield of these crops is very low as compared to other countries (Govt. of Pakistan 2010). For instance yield of wheat in India is about 8t/ha while in Pakistan it is $3-4 \mathrm{t} / \mathrm{ha}$. The yields of Sugarcane in Pakistan is 4045t/ha while India and Egypt produce 66t/ha and $110 \mathrm{t} / \mathrm{ha}$, respectively (FAO 2009). One of the most important factors responsible for low yield in Pakistan is the loss caused by weeds. Annual losses due to weeds on farmlands are far greater than realized. The figures would be alarming if these losses are interpreted in monetary terms. Studies show that the annual crop losses in Pakistan due to weeds range from $17-25 \%, 20-63 \%, 10-35 \%$ and $13-31 \%$ in wheat, rice, sugarcane and cotton crops, respectively (Abbas 2006). Hussain and Shahid (2001) reported that weeds reduce sugarcane yield by $45 \%$ and Nayyar et al. (1992) reported that weeds reduce wheat yield by $25-30 \%$. If the weeds are allowed to grow unchecked with no control measures the outcome would be cataclysmic (Pacanoski 2007).

Besides quantitative effects on yield, weeds deteriorate the quality of produce through the physical presence of their seeds and debris and also *Corresponding author : wahabextensionist@yahoo.com offer competition for water, nutrients, space and sunlight (Anderson 1983). As the weed problems are multi-pronged holistic multi-disciplinary integrated approach would be imperative. In this context, Integrated Weed Management (IWM) may provide a more sustainable approach to weed control (Maity and Mukherje 2009). Integrated weed management (IWM) is the control of weeds through a long-term management approaches, using several weed management techniques such as, Physical, Chemical, Biological, Cultural and preventive measures (Aulakh and Mehra 2006). IWM would help prevent weeds becoming resistant to herbicides on prolong exposure (Sanyal 2008). In Pakistan, farmers use combination of methods under the umbrella of IWM to eradicate weeds. They employ cultural measures (stale method, manual hoeing, crop rotation, burning, grazing), chemical control (use of herbicides), biological method (use of allellopathy and predator), mechanical measures (hoeing with plough or cultivator) and preventive measures (use of clean seed, clean tillage implements and machinery, cleaning of water channels etc.) (Riaz et al. 2006).

In the present paper an attempt was made to determine farmer perception regarding the comparative effectiveness of different elements of IWM in Punjab, Pakistan.

\section{MATERIALS AND METHODS}

Pakistan is comprised of four provinces namely Punjab, Sindh, Baluchistan and NWFP (which is now renamed as Khyber Pakhtoonkhwa) (Sharif 


\section{ABDUL WAHHAB ET AL: FARMER PERCEPTION ON WEED MANAGEMENT}

2004). The study was conducted in Punjab which comprises of 9 divisions. Through simple random sampling technique 3 divisions namely Faisalabad, Dera Ghazi Khan and Rawalpindi were selected. From these 3 divisions, 50 farmers were selected from each division randomly, thus making total sample of 150 farmers. The data were collected with the help of a well-structured and validated interview schedule (Wingenbach et al. 2003). A five point Likert type scale was utilized to record the perceptions of the farmers regarding the effectiveness of various extension education methodologies(Linder et al. 2003).

The collected data were analyzed using Statistical Package for Social Sciences (SPSS) (Davis et al. 2004). Descriptive statistics were used for the analysis of data (Bonne et al. 2002).

\section{RESULTS}

The survey revealed the effectiveness of various weed control measures under the umbrella of Integrated weed Management, the chemical methods were rated very good by almost threefourth of the growers (Table 1).

Very similar results were concluded by (Khan et al. 2004) who found that about $75 \%$ of the growers rated herbicide use for weed control as effective. More than one-third of the farmers perceived cultural methods as very effective. While thee-tenth of the respondents declared mechanical methods as very effective. Preventive tactics were averagely rated by $28.6 \%$ of the farmers. Only few farmers found to be using biological methods.

The weighted score, mean, standard deviation and rank order of the effectiveness of extension methods were calculated by multiplying the relative score values allotted to each category of scale with its frequency count (Table 2)

In terms of the effectiveness of various elements of Integrated Weed Management, Chemical method was found to be the most effective tool with mean value 4.54 and weighted score of 696. These findings are in accordance with those of (Khan et al. 2004) who found that use of chemicals to eradicate weeds proved to be the number 1 method among all techniques. Cultural method and mechanical method having mean values 3.71 and 2.52 , with weighted scores of 518, and 285 and were ranked as $2^{\text {nd }}$ and $3^{\text {rd }}$, respectively. Likewise, mean values of effectiveness of preventive measures and biological methods were found to be 0.79 and 0.55 , with weighted scores 110 and 8 and their rank orders were $4^{\text {th }}$ and $5^{\text {th }}$ respectively
Table 1: Distribution of respondents according to the extent of use of various elements of IWM

\begin{tabular}{llllll}
\hline IWM method & \multicolumn{5}{c}{ Response (\%) } \\
\cline { 2 - 6 } & $\begin{array}{l}\text { Very } \\
\text { poor }\end{array}$ & Poor & Average & Good & $\begin{array}{l}\text { Very } \\
\text { Good }\end{array}$ \\
\cline { 2 - 6 } Chemical & - & - & 9.3 & 17.4 & 73.3 \\
Cultural & 8.6 & 9.3 & 19.4 & 25.9 & 36.7 \\
Mechanical & 7.7 & 10.3 & 21.8 & 29.5 & 30.7 \\
Preventive & 32.2 & 39.3 & 28.6 & & \\
Biological & 40 & 60 & & & \\
Very poor=1, Poor=2, Average=3, Good=4, & \\
Good=5
\end{tabular}

Table2. Weighted score, mean, standard deviations (S.D) and rank order of the effectiveness various methods of Integrated Weed Management

\begin{tabular}{lllll}
\hline IWM methods & $\begin{array}{l}\text { Weighted Mean } \\
\text { score }\end{array}$ & S.D & $\begin{array}{l}\text { Rank } \\
\text { order }\end{array}$ \\
\hline Chemical & 696 & 4.54 & 0.86 & 1 \\
Cultural & 518 & 3.71 & 1.28 & 2 \\
Mechanical & 285 & 2.52 & 1.35 & 3 \\
Preventive & 110 & 1.96 & 0.79 & 4 \\
Biological & 8 & 1.6 & 0.55 & 5 \\
\hline
\end{tabular}

\section{DISCUSSION}

The above results depict information in the perspective of different measures of weed elimination under IWM. Chemical methods were perceived to be very effective because of their quick action and time and labour saving. However, the efficiency of

cultural methods was considered low as compared to chemical controls because of the longer time taken and high labour consumption. Regarding mechanical methods, the full scale control is hindered by non-availabity of machinery and less effectiveness. Preventive methods, although minimize the entry of weeds into the field, do not kill weeds, hence farmers regarded preventive methods not very effective. Overwhelming majority of farmers were unaware of biological methods and those farmers who knew biological control were dissatisfied this method because of lack of information and facilities.

\section{CONCLUSION}

Farmers in Pakistan use variety of techniques under Integrated Weed Management strategy. Considering the effectiveness, Chemical method (use of weedicides) was perceived be the most effective method used by growers. Cultural methods (crop rotation, manual hoeing etc.) ranked $2^{\text {nd }}$ and mechanical (use of plough or cultivar) got $3^{\text {rd }}$ position in the eyes of farming community. Preventive measures were ranked $5^{\text {th }}$ and biological 
measures being used only by a few members of farming community was ranked at last position.

\section{REFERENCES}

Abbas MA 2006General Agriculture. Publishers Emporium. Pp. 147.

Anderson WP 1983 Weed-crop competition. In: Weed SciencePrinciples, 2nd Ed, and Pp: 33-42. West Publication Co., St. Paul Minn, USA.

Aulakh CS and Mehra SP 2006 Integrated management of red sprangletop [Leptochloa chinensis (L.) Nees] in transplanted rice. Indian J. Weed Sci. 38, 225-229.

Boone HN, Gartin SA, Wright CB, Lawrence LD and Odell KS 2002 Adult education philosophies practiced by agricultural education teachers in Pennsylvania, Virginia, and West Virginia. J.Agric. Educ., 43: 37-48.

Davis K, Franzel S, Hildebrand P and Place N 2004 Extending Technologies among Small-Scale Farmers in Meru: Ingredients for Success in Farmer Groups. Proceedings of the 20th Annual Conference of Association for International Agricultural and Extension Education (AIAEE), Pp: 902-13. Dublin, Ireland.

FAO 2007 Statistical Year Book, FAO, Rome. Online available at www.fao.org.

Govt. of Pakistan 2010 Crops area and production. Ministry of Agriculture and Livestock. Economic and trade wing, Islamabad.

Govt. of Pakistan 2011 Economic Survey. Economic Advisor's Wing. Finance division,
Islamabad.

Hussain SZ and Shahid A 2001 Efficacy of preemergence application of different Herbicides in sugar cane. Pak. Sugar J., 14:45-50.

Khan H, Marwat KB, Khan MA and Khan N 2004 Distribution and Control of Broomrape (Orobanche spp.) And Other Major Weeds In District Swabi, NWFP. Pak. J. Weed Sci. Res. 10(3-4):193-200, 2004.

Lindner JR, Dooley KE and Wingenbach GJ 2003 A Cross-National Study of Agricultural Extension Education Competencies. J. Int. Agric. Extension Educ., 10: 51-9.

Maity SK and Mukherjee PK 2009 Integrated weed management practices in dry directseeded summer rice (Oryza sativa). Indian J. Agric. Sciences. 79, 976-979.

Nayyar MM, Shafi M, Shah ML and Mahmood T 1992 Weed eradication duration studies in wheat. In: Weed Management for Sustainable Agriculture. Proc. 4th All Pakistan Weed Science Conference, Pp: 147-53

Pacanoski Z 2007 Herbicide use: Benefits for a survey as a whole- A Review. Pak J. Weed Sci. Res. 13(1-2): 135-147, 2007.

Riaz M, Malik MA, Mahmood TZ and Jamil M 2006 Effect of Various Weed Control Methods on Yield and Yield Components of Wheat Under Different Cropping Patterns. Int. J. Agi. And Bio. 1560-8530/2006/08-5-636-640.

Sanyal D 2008 Introduction to the integrated weed management revisited symposium. Weed Sci. 56,140 . 